\title{
CULTURAL CONTENT ANALYSIS ON GOVERNMENT-ISSUED ENGLISH LEARNING TEXTBOOKS
}

\author{
Ryan Ghassan Albari ${ }^{1}$, Harumi Manik Ayu Yamin ${ }^{2}$ \\ ${ }^{1}$ English Studies Program, Faculty of Humanities, Universitas Indonesia, Depok, Indonesia \\ ryanghssn@gmail.com \\ ${ }^{2}$ Linguistics Department, Faculty of Humanities, Universitas Indonesia, Depok, Indonesia \\ harumi.m@ui.ac.id
}

\begin{abstract}
In today's world, the English language is seen as the international language for its worldwide use in all aspects of life. The language thus becomes the medium in bridging communication gaps between countries by providing a common ground for communication. To cater to the need of human resources with intercultural communicative competence (ICC), the government in Indonesia has issued textbooks for English learning for middle school students. In Indonesian national curriculum, English language is first formally learned in middle school, where the students are at the age of shaping their own ideology and values, which could also come from learning. This study examines the English textbooks issued by the government by analyzing their cultural content. The cultural elements are examined and divided into three components using the framework from Yuen's cultural elements, a modified version of Cortazzi and Jin's cultural aspects by Tazeddin \& Teimournezhad, and Gomez Rodriguez's surface culture and deep culture. The results show that the cultural content is disproportionate, and it might lead to the failure of creating ICC learners as it dismisses other aspects and elements of culture that are important in nurturing ICC.
\end{abstract}

Keywords: cultural aspects; cultural content; cultural elements; English learning textbooks; intercultural communicative competence; surface and deep culture.

In today's globalized world, the English language has been deemed as the international language for its frequent use. As English-speaking countries gain dominance in the world, the language established into the language of global science and technology, resulting in language expansion to other countries where English has never been spoken traditionally (Cenoz \& Jessner, 2000). As can be seen nowadays, the English language has become the medium in bridging communication gaps between countries by providing middleground for communication. In the Indonesian context, the current curriculum, Kurikulum 2013, considers learning English as local content. Local content is teaching plans where study materials and lessons are adapted to local environmental conditions and regional development needs (Arikunto, as cited in Lestari, 2012). The Ministry of Education and Culture in Indonesian categorized the English language as local content from the first grade of elementary 
until the last grade, and in middle school, the English language became a mandatory subject. To cater to the need of competent English-speaking human resources, the government has issued textbooks for English

<| 50 learning for middle school students. English textbooks for learning are needed as they contain extra assignments that will supply learners with more knowledge. These extra assignments aid them in learning English as students do not only acquire knowledge from reading books and listening to the lecturer, but also from triggers to think using other language. To add from Cortazzi and Jin (1999), "the textbook can be a teacher, a map, a resource, a trainer, an authority, a deskiller, and an ideology." From the definition, it can be concluded that besides serving as an aid by providing topical and linguistic exercises, textbooks also project ideologies, wherein cultural content is inherent in the books. The cultural content is very crucial in nurturing intercultural communicative competence, which will be explored deeper later.

There are myriad of ways in categorizing cultural content in a textbook, one of which is the one proposed by Cortazzi and Jin (1999). According to them, there are three types of culture, they are source culture, which is the learner's inherent culture; target culture, which is the culture of the second language learned (English in this context); and international culture, which refers to the culture from English speaking or nonEnglish speaking countries who use English as an international language. This framework treats all forms of cultural content as different from each other- Tajeddin and Teimournezhad (2014) agree with the proposed idea by the Cortazzi\&Jin with an addition to the theory. Tajeddin\&Teimournezhad added a fourth aspect named the "culture-free" aspect. The culture free aspect refers to culture elements that do not belong to any particular culture. Yuen (2011), in his research, uses theory to differentiate cultural elements by dividing the cultural elements into products, practices, perspectives, and persons. The surface and deep culture framework by Gomez Rodriguez (2015) divides culture into two: surface and deep culture. Surface culture is the visible, celebratory kinds of culture, while deep culture is the implicit, contentious kinds of culture.

The topic of cultural content in English learning textbooks has been researched for quite sometimes. Munandar \& Ulwiyah (2012) researched that Indonesian textbooks for the English language, using the 2006 Standard Contents of English stipulated by Indonesia's National Agency for Education Standards, are good enough for the students to foster their interculturality. According to their research, the cultural content of the textbooks is balanced in terms of source culture and target culture, making ICC achievable. However, a few years later, research from Sari (2017) and Rahmani (2018) found the opposite. At this time, the curriculum has already undergone a change from KTSP 2006 to the 2013 curriculum (Kurtilas). Sari and Rahmani both argued that the textbooks are not suitable to nurture ICC. Sari argues that the books are not suitable for promoting ICC because they focus too much on universal-across-culture elements, which she claimed to be not helpful. Rahmani argues that the books she researched are too heavy on target culture elements, claiming they will not be helpful either because they leave the learner with minimum exposure of Indonesian culture. The issue about nurturing ICC in students is not only garnering the attention of Indonesian scholars but also scholars from other countries. Research in Malaysia is done 
by Rahim and Dagigh (2019), using a comparative approach between a locally developed textbook and an imported textbook, shows that the local textbook has a more comprehensive intercultural content than the international textbook. Research on textbooks has also been done in Mexico. Gomez Rodriguez (2015) takes on a different approach to doing his research. Rather than categorizing the cultural content the same way as Cortazzi and Jin, he used a different theoretical framework by categorizing the culture into two: surface culture and deep culture.

In researching this topic, some gaps were discovered from the earlier research made by other scholars. The research done by Munandar has the same intention as this research, but the books that are used for the research are the books that use the 2006 curriculum. The research done by Sari analyzed the cultural content in English textbooks that use the 2013 curriculum, but she only researched from one book, and the research only covered the vocabulary section. The research done by Rahmani analyzed cultural content in textbooks also, but the textbooks that are used are for tertiary education. Although there have been many research findings regarding cultural content in textbooks, there are still few research findings on textbooks for secondary education. Hence, this research focuses on the analysis of cultural content present in English textbooks used by middle school students in a series of middle school English textbooks issued by the government. The leading theory that is going to be used for this research will also have some differences from the previous research mentioned here.

All of the research has been dealing with the kind of cultural content in the books. The author will also use the surface culture and deep culture theory to analyze the corpus, which includes the reading section of the books. While using the surface and deep culture theory has been used in some international research, it has never been used in the context of Indonesian governmentissued textbooks. The research questions are then formulated as:

a. How are the cultural elements distributed in the books?

b. How are the cultural aspects distributed throughout the books?

c. How do the books include surface culture and deep culture in their chapters?

This research aims to see whether or not the government-issued textbooks have ample cultural elements to nurture the intercultural communicative competence of the students. This research looks at the overview of the cultural content in the English textbooks published by the government.

\section{METHOD}

In conducting this research, three English textbooks were chosen. The textbooks were chosen because the government issued them; thus, the distribution of the books is nation-wide. Three textbooks were analyzed; each of them is meant to be used for students in grades 7 9. The titles for the textbooks are; Bahasa Inggris: When English Rings a Bell for grade 7 and 8, and Bahasa Inggris: Think Globally Act Locally for grade 9. Books for middle school students were chosen because, at this age, the middle school students are in the age of early adolescence. Early adolescence is the age of wonder, where at this age, students are in the process of finding identity and values for the first time (Salyer \& McKee, n.d.) Thus, as a significant source of ideology, English textbooks, as well as any other books, play an essential role in shaping the identity and values of its learners through the knowledge transferred. 
In analyzing the books, this research adopts the framework from Yuen (2011), a modified framework of Cortazzi \& Jin (1999) by Tajeddin and Teimournezhad (2014) and Gomez Rodriguez (2015). The theory from $<\mid 52$ Yuen is used to categorize the cultural content presents in the books into cultural elements. The modified theory of Cortazzi \& Jin by Tajeddin and Teimournezhad is used to further categorize the cultural elements into cultural aspects of source culture, target culture, international culture, and culture free items. The cultural aspects are then categorized into surface culture and deep culture. This helps to see whether or not the textbooks contain ample cultural contents. In doing the steps above, there are also discussions with lecturers and English studies program students to make sure the categorizations are correct. The results are tabulated in percentages to make it easier to be analyzed.

\section{Data Analysis}

The data are analyzed through a three-stage process proposed by Miles and Huberman (2012). According to them, the stages to analyze data are 1) data reduction (simplifying complex data, for example, extracting themes via coding) 2) data display (displaying data using charts, matrix, graph, etc.); and, finally, drawing conclusions and verifying the data analyzed. As mentioned above, the first thing to do is to reduce the data by using a checklist for coding. All of the data needed in this will be input in checklists.

\section{Constructing the checklist}

There are two checklists used to determine the cultural elements, cultural aspects, and surface \& deep culture. These checklists function as an instrument for coding the three cultural components. Each checklist is made using the three frameworks separately. The findings of the data are tabulated in percentage and filled in each findings section in the table.

\section{Cultural Elements}

Yuen (2011) classified the cultural elements into four, which are products, practices, perspectives, and persons. Products refer to human-made artifacts, such as books, stories/folklores, music, daily items, foods, names, etc.

a) That is a post office (Book VII, Chapter IV, p. 67)

b) I have two rubbers. What about you, how many pens do you have? (Book VII, Chapter IV, p. 63)

Practices refer to cultural items in forms such as rituals, daily activities, habits, ceremonies, etc.

a) It is Sunday. It is five o'clock. Edo gets up and takes a bath

b) When is your birthday?

Perspectives refer to a certain point of view of a group of people from a particular culture regarding values, norms, or family relations.

a) Both my mom and my dad are very good cooks (Book VIII, Chapter VII, p. 95)

b) Our classroom is dirty and messy (Book VIII, Chapter III, p. 37)

Persons refer to a famous person from a particular culture.

a) 93 Million Miles by Jason Mraz (Book IX, Chapter XI, pp. 204-205)

b) Orphan by Toto (Book IX, Chapter VI, p. 127)

\section{Cultural aspects}

According to Cortazzi and Jin (1999), there are three aspects of culture, which are source culture, target culture, and international culture. However, Tajeddin and Teimournezhad (2014) added a fourth aspect, which is culture free. Source culture (SC) refers to the learner's own culture; in this research context is Indonesian culture. For example: 
a) Lemper is made of a handful lump of steamed glutinous rice (Book IX, chapter VIII, p. 147)

b) Hi, Lina. I heard that you (visit) CintaKasih orphan home yesterday (Book IX, chapter VI, p. 123)

Target culture (TC) refers to the culture of the language that learners are learning; in this context is the language of Englishspeaking countries (the United Kingdom and the USA).

a) 93 Million Miles by Jason Mraz (Book IX, chapter XI, p. 204)

b) Count On Me by Bruno Mars (Book VII, chapter VIII, p. 179)

International culture (IC) refers to the culture where learner's language and the target language is not spoken, meaning the culture from other countries besides the learners' and English-speaking countries.

a) The story of the Golden Star Fruit Tree from Vietnam (Book IX, chapter VII, p. 140)

Culture neutral $(\mathrm{CN})$ refers to the cultural item that does not convey any particular culture.

a) We must not be late to school (Book VIII, Chapter III, p. 41)

\section{Surface Culture and Deep Culture}

Surface culture and deep culture are essential aspects that need to be present in English learning textbooks. However, the EFL field has been generally focused on teaching elements of surface culture, that is, the easily observable (Hinkel, as cited in Gomez Rodriguez, 2015). Surface culture deals with the tangible forms of culture, such as holidays and tourist sites. On the other hand, deep culture is the invisible form of culture that reflects the society of a particular culture, for example, lifestyle, beliefs, and values (Gomez Rodriguez, 2015). While surface culture is needed to better visualize and give context to learners, the presence of deep culture is also needed since culture goes beyond those superficial principles

\section{FINDINGS}

Cultural Elements and Cultural Aspects in English Textbook for Grade 7

To answer how the cultural elements in the books are distributed, we can see it from the table and chart below. There are 819 occurrences of cultural elements in which Products appear to be the element that occurs the most in the textbook. Products (P1) appear as much as 550 times, which accounts for $67 \%$ of the cultural elements that the book served. The next cultural element that appears the most is Practices (P2). Practices occur 210 times throughout the chapters, accounting for $26 \%$ of the cultural elements that are distributed in the textbook. Perspectives (P3) only have 57 occurrences in the textbook, which accounts for $7 \%$ of the cultural elements included in the book, and Persons (P4) has almost no occurrence in the textbook. 


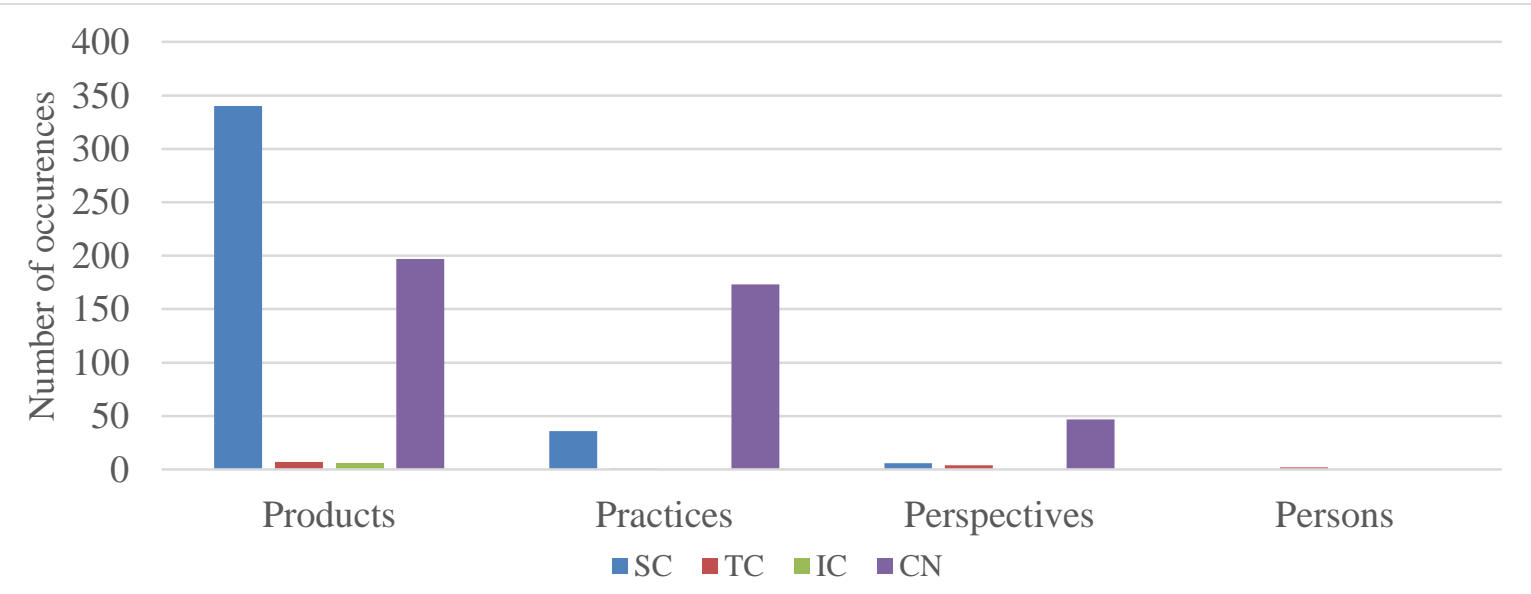

Cultural elements and cultural aspects

Figure 1. Cultural elements and cultural aspects in English learning textbook for grade 7

Table 1. Cultural elements and cultural aspects in English learning textbook for Grade 7

\begin{tabular}{llllll}
\hline & P1 & P2 & P3 & P4 & Total \\
\hline SC & 340 & 36 & 6 & 0 & 382 \\
\hline TC & 7 & 1 & 4 & 2 & 14 \\
\hline IC & 6 & 0 & 0 & 0 & 6 \\
\hline CN & 197 & 173 & 47 & 0 & 417 \\
\hline Total & 550 & 210 & 57 & 2 & 819
\end{tabular}

Table 1. Cultural elements and cultural aspects in English learning textbook for Grade 7

To answer how the cultural aspects in the book are formulated, we can also see from the table above that most aspect of the culture belongs in the culture neutral $(\mathrm{CN})$ area. The culture neutral aspects are those of culture that do not necessarily belong to a particular culture, for example, classification of family members. It does not belong to one particular culture. The culture neutral aspects appear 417 times or $51 \%$. The second aspect that appears the most is the source culture (SC) aspect, with 382 appearances or $47 \%$ spread throughout the chapters. The source culture aspects mainly come in forms of names of people, such as Edo, Lina, Beni, Siti, and more. The last two aspects, target culture (TC) and international culture (IC), were the lowest-numbered aspects that are featured in the textbook. Whereas the target culture aspect has 14 occurrences or $1.5 \%$ appearances in the textbook, mainly for songs from American artists like Bruno Mars and Michael Jackson, the international culture aspects only account for six occurrences or $0.5 \%$ from the mention of African and Asia continents.

Surface and Deep Culture in English Textbook for Grade 7 
The analysis regarding surface and deep culture in the English textbook for grade 7 shows that except for the last two chapters, the other chapters do not include surface culture in the teaching curriculum. A lot of the cultures presented in the seven chapters are all forms of congratulatory and tangible culture, and the chapters except the last one talk about the typical culture of greetings, self, time, objects, and Indonesia. These themes are said to be congratulatory since they glorify the emblematic symbols of the cultural elements that are happening in

Table 2. Surface culture and deep culture in English learning textbook for 7th grade

\begin{tabular}{|c|c|c|c|}
\hline Chapter Title & Surface Culture & Deep c & culture \\
\hline $\begin{array}{l}\text { Good Morning. How } \\
\text { Are you? }\end{array}$ & $\begin{array}{l}\text { - How to greet other people } \\
\text { - The differences in greetings } \\
\text { according to time } \\
\text { - Dialogues of people greeting } \\
\text { each other }\end{array}$ & None & \\
\hline This is $\mathrm{Me!}$ & 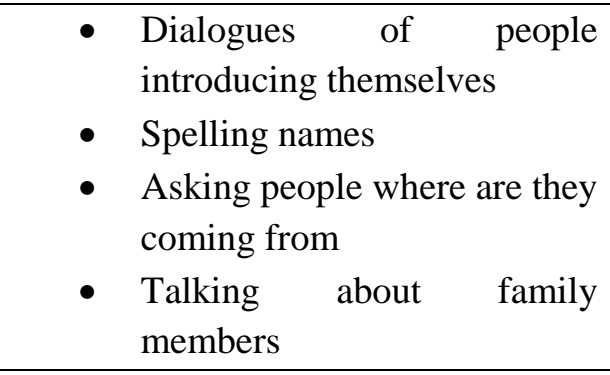 & None & \\
\hline What Time is it? & $\begin{array}{l}\text { - Learning how to tell time, } \\
\text { date, day, and month } \\
\text { - Daily activities } \\
\text { - National days in Indonesia }\end{array}$ & None & \\
\hline This is My World & $\begin{array}{l}\text { - Stating objects in different } \\
\text { areas in home } \\
\text { - Stating the characteristics of } \\
\text { the objects }\end{array}$ & None & \\
\hline It's a Beautiful Day & $\begin{array}{l}\text { - Stating qualities of a person } \\
\text { or an object } \\
\text { - Criticizing or praising a } \\
\text { person or an object }\end{array}$ & None & \\
\hline We Love What We do & $\begin{array}{ll}\text { - } & \text { Asking and giving } \\
\text { information about a person or } \\
\text { an object } \\
\text { - } \begin{array}{l}\text { Describing non-human } \\
\text { objects }\end{array}\end{array}$ & None & \\
\hline I'm proud of Indonesia & $\begin{array}{l}\text { - Describing characteristics of } \\
\text { a place, animal, objects, and } \\
\text { human } \\
\text { - Geographical conditions of } \\
\text { Indonesia } \\
\text { - Objects that are relevant to }\end{array}$ & & $\begin{array}{l}\text { Some dialogues } \\
\text { containing messages } \\
\text { that there is still } \\
\text { uneven development in } \\
\text { Indonesia especially in } \\
\text { the rural areas }\end{array}$ \\
\hline
\end{tabular}


everyday life

That's What Friends are • A song by Bruno Mars

Supposed To Do
- The song teaches the children about friendship through Bruno Mars' song You Can Count on Me and what it means to have a friend that you can always count on.
For example: in the chapter that mentions national holidays, the chapter only lists the national holidays in Indonesia. It may be seen as a deep culture because the author's intention might be to foster nationalism. However, it did not discuss why that particular day became the national holiday. It only tells the learners to celebrate those days without knowing the background story of the days. The last chapter talks about the deep culture by using the song from Bruno Mars titled You Can Count on Me. The deep culture element is taken from the message of the song that friends must be cherished, and as a friend, we can always count on each other. However, the chapter was only three pages long, and the song is the only primary reading of the chapter. Hence, the deep culture present in the chapter is not ample enough to nurture ICC. Another example is from the chapter "I'm proud of Indonesia!" In this chapter, there are a lot of dialogues and readings that describe Indonesia. However, they only carry the emblematic symbols of Indonesia, which says that Indonesia is an agrarian state, that Indonesia offers beautiful places to visit, and that Indonesia is a heaven for tourists. However, some readings contest this view. For example:

"There is a lake near my hometown. It's very large and panoramic. The forest around the lake is very green and cool. But, I want to say some sad things about it. It is very dirty, and the foods and drinks are very expensive. People litter everywhere because there are not many garbage bins there. The vendors leave their waste everywhere. Some wooden benches are broken, so we cannot sit on them.'

The excerpt above shows that in some places in Indonesia, especially the rural area, the emblematic symbols mentioned before are not always the characteristics of every place in Indonesia. While some other readings in this chapter might reduce the complexity of the country by perceiving Indonesia as the "paradise," some readings like the above excerpt contest to that notion, this is an excellent example to build ICC since it offers different perspectives and creates culturally aware individuals. However, the amount of this kind of deep culture is still too little compared to the congratulatory topics that are present in the book.

\section{Analysis of Cultural Elements and Cultural Aspects in English Textbook for Grade 8}

Analysis of book 2 of the textbook series also shows that there are similarities in how the authors formulate and distribute the cultural elements. As seen in the table below, we can see the element that occurs the most is products, numbering in 494 , or $62 \%$ of the 
total of the book. The products appear to be names of people, places, and also objects. In the second book, the number of practices also comes in second place. There are 190 occurrences of practices that are presented in the book throughout the whole chapters. The occurrences come in the form of ceremonies, rituals, and daily habits, such as flag ceremonies and a person's activity in a day. Overall, practices element covers $24 \%$ of the cultural dimensions mentioned in the book. Perspectives also have the same pattern as the previous book. It ranks third in the context of cultural elements that are included in the textbook with the number of 109. It contributes to $14 \%$ of the portion of cultural elements in the book. The majority of perspectives element in the textbook comes from the appearance of family membersrelated topics. The last and least cultural element that occurs in the book is persons. It only occurs two times; one of them mentioned the name of a band that used to exist, One Direction.

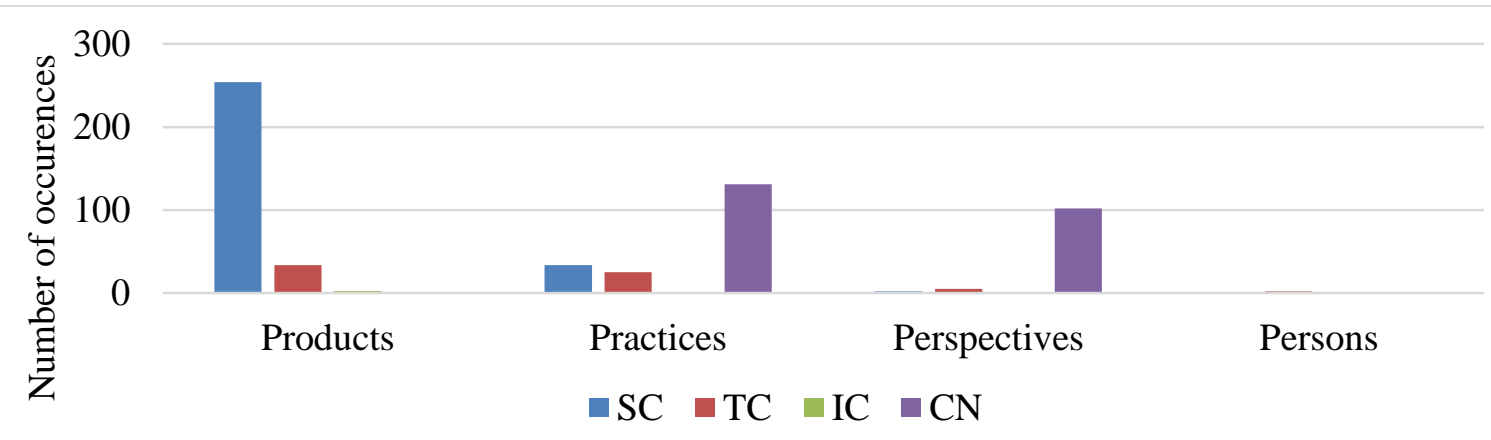

Cultural elements and cultural aspects

Figure 2. Chart of cultural elements and cultural aspects in English learning textbook for grade 8

\begin{tabular}{llllll}
\hline & P1 & P2 & P3 & P4 & Total \\
\hline SC & 254 & 34 & 2 & 0 & 290 \\
\hline TC & 34 & 25 & 5 & 2 & 66 \\
\hline IC & 2 & 0 & 0 & 0 & 2 \\
\hline CN & 204 & 131 & 102 & 0 & 437 \\
\hline Total & 494 & 190 & 109 & 2 & 795
\end{tabular}

Table 3.Cultural elements and cultural aspects in English learning textbook for Grade 8

The cultural aspects that are included in the book once again show the same pattern as the first book. The aspect occurring the most in the textbook is the culture-neutral aspect of the book. Overall, it manages to occur 437 times or $55 \%$ of the whole textbook. The second aspect is the source culture aspect numbering at 290 occurrences or $37 \%$ of the whole book. Target and international culture aspects became the lowest occurrences in the whole book, which number in 66 and 2 occurrences or $8 \%$ and $0.01 \%$, respectively. 
Analysis of Surface Culture and Deep Culture in English Textbook for Grade 8

Table 4. Surface culture and deep culture in English learning textbook for 8th grade Surface Culture

Deep Culture

It's English Time

- Talking about the None

activities that are done by

the people at school

\begin{tabular}{|c|c|c|c|}
\hline $\begin{array}{l}\text { We can do it, and } \\
\text { we will do it! }\end{array}$ & $\begin{array}{ll}\text { - } & \text { Stating capability in } \\
\text { doing something }\end{array}$ & None & \\
\hline $\begin{array}{c}\text { We know what to } \\
\text { do }\end{array}$ & $\begin{array}{l}\text { - } \\
\text { - } \quad \text { Do's and don'ts in class } \\
\text { and school }\end{array}$ & & $\begin{array}{l}\text { The chapter gives insight } \\
\text { into the rules and } \\
\text { obligations of students in } \\
\text { Indonesia (wearing batik } \\
\text { uniform every Thursday } \\
\text { and obligatory flag } \\
\text { ceremony every Monday) } \\
\text { and how those } \\
\text { emblematic symbols help } \\
\text { learners develop their } \\
\text { nationalism. }\end{array}$ \\
\hline
\end{tabular}

\begin{tabular}{|c|c|c|c|}
\hline $\begin{array}{c}\text { Come to my } \\
\text { birthday, please! }\end{array}$ & $\begin{array}{ll}\text { - } & \text { Birthday invitation } \\
\text { - } & \text { Asking and giving } \\
\text { permissions }\end{array}$ & None & \\
\hline $\begin{array}{l}\text { I'm so happy for } \\
\text { you! }\end{array}$ & - Making greeting cards & None & \\
\hline Our busy roads & $\begin{array}{l}\text { - Stating about the } \\
\text { existence of peoples and } \\
\text { objects } \\
\text { - Michael Jackson's song } \\
\text { Heal The World }\end{array}$ & $\bullet$ & $\begin{array}{l}\text { Some texts in the chapter } \\
\text { once again talk about } \\
\text { social discrepancies } \\
\text { Indonesia, for example, } \\
\text { the damaged roads in the } \\
\text { rural areas } \\
\text { A call for action from the } \\
\text { song of Michael Jackson, } \\
\text { heal the world. }\end{array}$ \\
\hline $\begin{array}{l}\text { My uncle is a } \\
\text { zookeeper }\end{array}$ & $\begin{array}{l}\text { - Zoo animals } \\
\text { - Daily routines of } \\
\text { zookeepers } \\
\text { - A typical day in the life } \\
\text { of the characters of the } \\
\text { book }\end{array}$ & None & \\
\hline $\begin{array}{c}\text { What are you } \\
\text { doing? }\end{array}$ & $\begin{array}{l}\text { - Asking about somebody } \\
\text { else's activities }\end{array}$ & None & \\
\hline Bigger is not always & - Comparing things & None & \\
\hline
\end{tabular}




\begin{tabular}{cclll}
\hline \multicolumn{1}{c}{ better } & & & \\
\hline When I was a child & $\bullet$ & $\begin{array}{l}\text { Stating events that None } \\
\text { happened in the past }\end{array}$ \\
\hline Yes, we made it! & $\bullet$ & $\begin{array}{l}\text { Talking about one's None } \\
\text { experience and why they } \\
\text { are proud and can learn } \\
\text { from that experience }\end{array}$ & & \\
& $\bullet$ & $\begin{array}{l}\text { Giving commands to None } \\
\text { somebody else }\end{array}$ & & \\
\hline $\begin{array}{c}\text { Don't forget it, } \\
\text { please! }\end{array}$ & $\begin{array}{l}\text { Song by One Direction } \\
\text { titled History }\end{array}$ & & $\begin{array}{l}\text { Giving lesson to create } \\
\text { good memories with } \\
\text { friends }\end{array}$ \\
\hline We got a lot of & &
\end{tabular}

The chapters in book 2 also reveal the same result as with book 1 . Though surface culture is still more dominant compared to deep culture, the number of deep culture presented in book 2 is more prominent than those in book 1 . Out of 13 chapters, three chapters contain surface culture, while in book 1 , there are only two chapters. The example of is a tradition in Indonesia schools, especially in public schools. The other two chapters that contain deep culture is similar to the book for grade 7. It talks about the discrepancies in development between areas in Indonesia, and the other one talks about the meaning of a song.

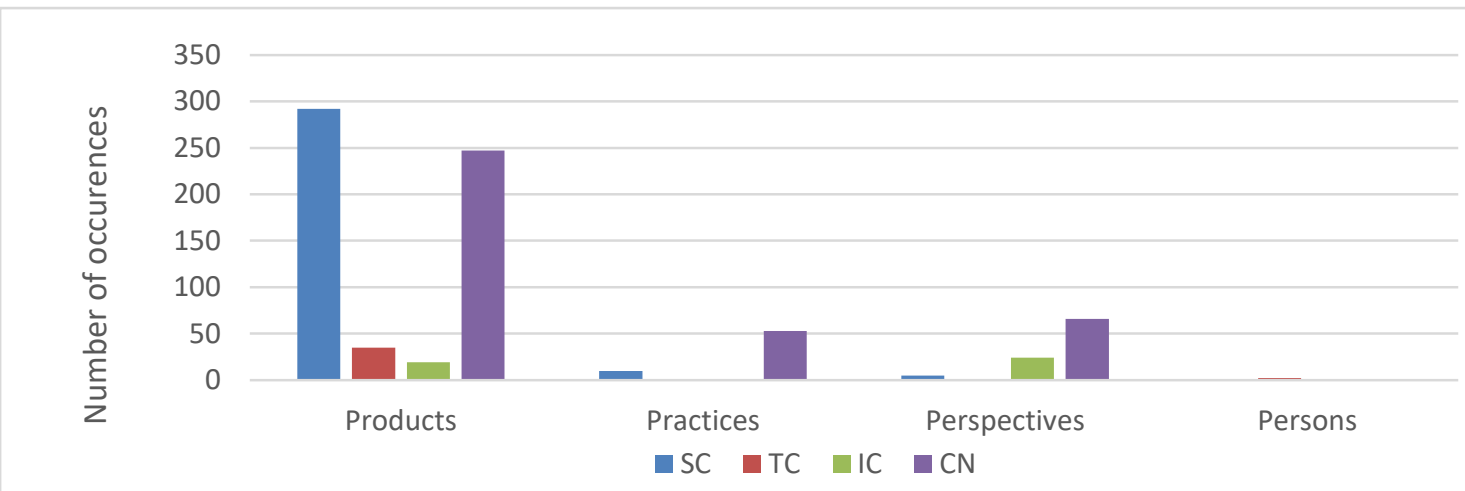

Cultural elements and cultural aspects

deep culture shown in textbook 2 is about Analysis of Cultural Elements and wearing uniforms to school. One of the texts mentions that every Thursday, all of the Cultural Aspects in English Textbook for Grade 9 students must wear Batik as the uniform. It is suggested from the books that wearing Batik

Figure 3. Chart of cultural elements and cultural aspects in English learning textbook for grade 9

English learning textbook for grade 9 has the lowest cultural elements among the three books. The textbook has a total of 754 occurrences of cultural items, and just like the previous two books, the element of Products covers more than half of it. There 
are 593 occurrences of products elements in the book, which means it covered $79 \%$ of the book. The products also mostly consist of names and objects. The second element that appears the most is perspective with 95 occurrences or about $13 \%$ of the whole book. The perspectives come in the form of family relations as well as point of view in a particular cultural setting. The two lowest elements are practices and persons. Practices have 64 occurrences in the book. The number accounted for about $8 \%$ of the whole book, while persons only have two occurrences, meaning it only accountable for $1 \%$ of the whole book.

Table 5.Cultural elements and cultural aspects in English learning textbook for grade 9

\begin{tabular}{llllll}
\hline & P1 & P2 & P3 & P4 & Total \\
\hline SC & 292 & 10 & 5 & 0 & 307 \\
\hline TC & 35 & 0 & 0 & 2 & 37 \\
\hline IC & 19 & 1 & 24 & 0 & 44 \\
\hline CN & 247 & 53 & 66 & 0 & 366 \\
\hline Total & 593 & 64 & 95 & 2 & 754 \\
\hline
\end{tabular}

The cultural aspects of the English learning textbooks for grade 9 are mostly dominated by culture-neutral items numbering at 366 , which accounts for $49 \%$ content of the book. Source culture becomes the second-highest aspect, with 307 occurrences in the book. The source culture comes from the name of Indonesian people as well as foods and objects, for example, angklung, lemper ${ }_{s}$ and sambel. Source culture managed to cover $41 \%$ of the book. The last two aspects rank the lowest. International culture has 44 occurrences across the book. The international culture aspect mostly comes from the international folktale that is presented in the book. The international aspect covers $6 \%$ of the book. Ironically, target culture aspects come the lowest with only 37 occurrences. This mainly comes from the name of the target culture; people such as Bill and Harry. The target culture aspects only cover about $4 \%$ of the book.

\section{Analysis on Surface Culture and Deep Culture in English Textbook for Grade 9}

Table 6. Surface culture and deep culture in English learning textbook for grade 9

\begin{tabular}{lcll}
\hline \multicolumn{1}{c}{ Chapter Title } & \multicolumn{1}{c}{ Surface Culture } & Deep Culture \\
\hline Congratulations! & Hopes and greetings & None & None \\
\hline Let's live a healthy life! & $\bullet$ & Giving advice & \\
& $\bullet$ & Agree and disagree & \\
\hline Be healthy, be happy & $\bullet$ & How to consume & None \\
& & particular medicine or \\
& food & \\
& $\bullet$ & Nutritional Facts of the \\
& & \\
& & food & \\
\hline This is how you do it! & $\bullet$ & Reading about recipes & None \\
\hline
\end{tabular}




\begin{tabular}{|c|c|c|c|}
\hline & and manuals & & \\
\hline $\begin{array}{l}\text { Everybody is always in the } \\
\text { middle of something }\end{array}$ & $\begin{array}{l}\text { Explaining activities in } \\
\text { progress at the time of } \\
\text { speaking }\end{array}$ & None & \\
\hline $\begin{array}{l}\text { We have been to an orphan } \\
\text { home. We went there last } \\
\text { Sunday }\end{array}$ & $\begin{array}{l}\text { - } \text { Visiting an orphanage } \\
\text { - } \quad \text { Life at the orphanage }\end{array}$ & None & \\
\hline Sangkuriang & $\begin{array}{l}\text { - Indonesian folktale: } \\
\text { Sangkuriang } \\
\text { - Vietnamese folktale: The } \\
\text { Golden Star-fruit Tree }\end{array}$ & • & $\begin{array}{l}\text { From Sangkuriang, we } \\
\text { learned that we always } \\
\text { have to respect our } \\
\text { parents, care for animals, } \\
\text { and also control our lust } \\
\text { From The Golden Star- } \\
\text { fruit Tree, we learned that } \\
\text { greed brings trouble. }\end{array}$ \\
\hline They are made in Indonesia & 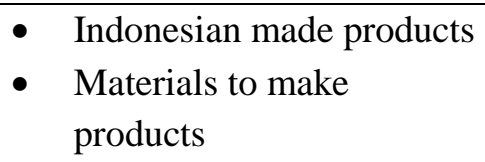 & None & \\
\hline What is it? & $\begin{array}{ll} & \text { Obtain and share } \\
\text { information about things }\end{array}$ & None & \\
\hline Come and visit us! & $\begin{array}{ll}\text { - } & \text { Promotion on products } \\
\text { and services }\end{array}$ & None & \\
\hline $\begin{array}{l}\text { You can always come back } \\
\text { home }\end{array}$ & $\begin{array}{l}\text { - } 93 \text { Million Miles by Jason } \\
\text { Mraz }\end{array}$ & & $\begin{array}{l}\text { The song talks about even } \\
\text { though life is hard, you } \\
\text { will always have to carry } \\
\text { on. However, your family } \\
\text { and friends will always } \\
\text { cheer you on. }\end{array}$ \\
\hline
\end{tabular}

The surface and deep culture in the last book have the same proportion as the book for 7 th grade. There are only two chapters that present us with deep culture out of eleven chapters. The first deep culture element can be seen in chapter VII titles Sangkuriang. Sangkuriang is a folktale that comes from West Java that tells a story about a young man named Sangkuriang, who wanted to marry his mother, Dayang Sumbi. From this story, the learners can learn that as humans, we always have to respect our parents, care for animals, and also control our lust. Another story from this chapter also gives us another deep culture in different cultural settings. The story of The Golden Star-fruit
Tree is a folktale from Vietnam, which tells about the life of two brothers; one is kind and humble, while the other one is greedy. This story conveys a message that greed will only bring trouble for people. The other chapter that presents deep culture is the last culture that uses Jason Mraz's song 93 Million Miles that talks about even though life is hard, learners will always have to carry on. However, family and friends will always cheer them on.

\section{Data from The Three Books Combined}




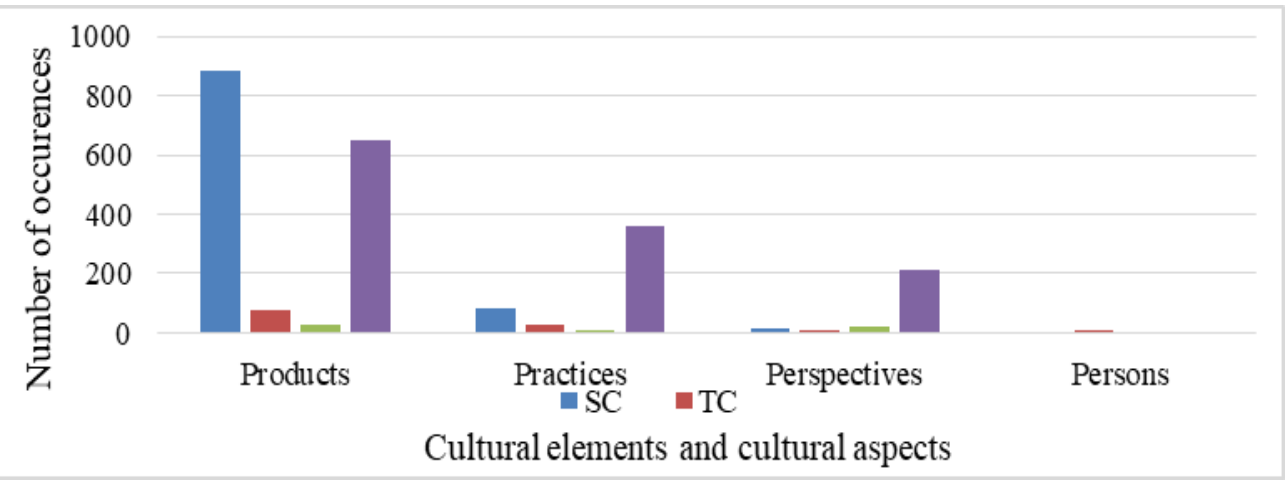

Figure 4.Culture elements and culture aspects from the three books combined

\begin{tabular}{llllll}
\hline & P1 & P2 & P3 & P4 & Total \\
\hline SC & 886 & 80 & 13 & 0 & 979 \\
\hline TC & 76 & 26 & 9 & 6 & 117 \\
\hline IC & 27 & 1 & 24 & 0 & 52 \\
\hline CN & 648 & 357 & 215 & 0 & 1220 \\
\hline Total & 1637 & 464 & 261 & 6 & 2368
\end{tabular}

Table 7. cultural elements and cultural aspects in English learning textbooks combined

In total, there are 2368 of cultural items that cultural aspects, culture-neutral items appear occurred in the three books. As you can see, the most, numbering at 1220 occurrences, or for the cultural elements, products occurred $52 \%$ of the books combined. The second the most with a total of 1637 occurrences or highest aspect to occur is source culture, about $69 \%$ of the total. The next one is with 979 occurrences or $41 \%$. Target culture practices with 464 and perspectives with 261 and international culture have the lowest occurrences, making it account for $20 \%$ and amount among others in which target culture $11 \%$, respectively. Persons has the lowest has a 5\% occurrence, while international amount of occurrences. It only occurs six culture only has a $2 \%$ occurrence. times or about less than $1 \%$. In terms of

Surface Culture and Deep Culture

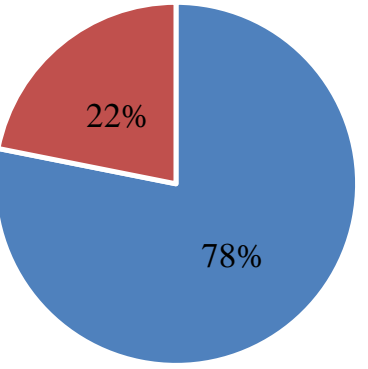

- Surface Culture - Deep Culture 
Figure 5. Surface culture and deep culture in English learning textbooks combined

The surface culture and deep culture ration can be seen from the chart above. Out of 32 chapters from the three books combined, there are only seven chapters that present us with deep culture materials. The other 25 chapters onlypresent the learner with pure emblematical culture. It is safe to say that the ratios for surface culture and deep culture in the three books are arranged in an imbalanced proportion.

\section{The Elements of Culture}

The elements of culture of the three books are divided into four elements. From the three books combined, we can see that the number of elements that are presented is not proportional. Products are the element that appears the most in the three books. It accounts for more than half of the total occurrences from the three books combined. Practices, perspectives, and persons occupy the second-highest to lowest positions in that order. The elements of culture created a whole dynamic system that governs a particular community in a particular cultural setting, but we must also note that culture is not only in the form of tangible items. From the data, we see that products, which are mostly tangible items, are dominating the elements in the three books. This would create a "tourist's perspective" in which learners are more interested in the tangible objects, such as food, entertainment, and travel, rather than acquiring a more in-depth cultural knowledge (Yuen, 2011).

\section{The Aspects of Culture}

The overall number of culture represented in the book also have imbalances. As foreign language learning books, they are heavily partial to culture-neutral and source culture aspects. According to Tajeddin \& Teimournezhad (2014), culture-neutral items are cultural items that may be present in most cultures, and the presence of it does not belong to one particular culture. Hamiloğlu and Mendi (2010) in their study claimed that there are three reasons why the authors put more cultural-neutral items in their books: the writer's values and awareness, political restraints from the publisher, and also cultural policies from the local authorities. In Indonesia, the last reason may be the case because while improving learners' crosscultural understanding is the government's main agenda, their number one mission is also to "Create strong educational and cultural performers" (Kemdikbud.go.id). Indonesian government is very keen in upholding the Indonesian culture, so the use of target and international culture are not very prominent. Instead, they use culture neutral items so that the students will still be exposed to "variety of other culture." Source culture is the second most apparent culture in the textbooks. It covers $41 \%$ of all the textbooks combined. Source culture is needed in foreign language textbooks as it becomes the transitioning bridge from the local context to the international context and also to create awareness of their own identity. However, in terms of these textbooks, they become a problem since the source culture aspects dominated the target and international culture aspects. Cortazzi and Jin (1999), in their research, argued that English learning textbooks with many references to source culture are not suitable to nurture cross-cultural communication since it may lead to miscommunication. English language learners who learn English with source culture context might able to speak English only in the context of their own culture, but if they are faced with people from different culture, the lack of exposure to other culture hinders effective 
communication since they cannot place themselves in another cultural context.

\section{Surface Culture and Deep Culture}

The overall amount of surface culture and

deep culture in the three books is also a significant problem. As we see from the data earlier, the scale is hefty on the surface culture side. Surface culture and deep culture are both needed in English learning textbooks to create ICC learners, but these books prove their shortcomings from the lack of deep cultural content. Through deep culture, learners do not only see the emblematic symbols that are mainly shown, but also the underlying value that comes with it. Deep culture becomes the tool for learners to be critical as it invites the learners to think about the hidden values of a culture, thus creating a more profound cross-cultural awareness lesson for the learner. As Olaya and Gómez Rodriguez (2013) claimed in their research, "not only celebrating cultures but establishing critical views can empower (learners) to develop critical ICC." This suggests learners must be exposed not only to the "pre-conceived notion" of a culture, but also the contentious, dynamic, and questionable side of culture.

\section{CONCLUSION}

As the goal of learning English in Indonesia proposed by the Ministry of Education and Culture is to let learners participate efficiently in the international communication scene, ICC is very much needed by the learners. However, contrary to the government's aim, the textbooks issued are not in-line with their goal of creating intercultural communicative competent learners as culture neutral aspects, source culture aspects, and surface culture materials heavily influence those books. The result obtained from the research confirms the research done by both Sari and Rahmani in the context of foreign language learning books for Indonesian learners. The cultural content in the books is arranged in an imbalance portion, and as a result, the textbooks are not suitable for the government's aim to create ICC learners. As we all know, ICC aims to create speakers who speak a foreign language not only in their cultural context but also place themselves in the context of the culture of the foreign language, but the books fell short in doing so due to the lack of exposure of other culture.

While creating culturally-aware performers may be the main reason that the government emphasizes culture-free, source culture, and surface culture items, books with this kind of characteristics tend to hinder effective intercultural communication since learners are mostly incapable of putting themselves in the international language context, which in turn will become a classic setup for miscommunication. It is also important to highlight that the learners that are using these books are young adolescent in the age of finding values and identities for the first time. Cortazzi and Jin (1999) emphasize that books are ideological devices, meaning that they have values that will be transferred to the learners. As Weninger and Kiss (2013) note in their article, "Textbooks thus play a pivotal role in the success of language education is socially transformative agenda' which means that it is essential to create books that encompass all aspects and elements of culture to make sure ICC is transferred to learners. This implication indeed suggests that the government need to re-formulate the English textbooks to contain more diverse aspects of culture and to include more deep cultures in the books.

This study is an overview of the cultural content that is presented in the 
English learning textbooks issued by the Indonesian government. While it is good to maintain source culture to instill Indonesian values, this research found that the imbalance in the amount of source culture compared to other culture elements made this government-issued books attempt to create ICC quite futile since learners more likely will use the English language in local context rather than international context. To prevent this from happening, it is better if the government enriches the book by providing more diverse cultural content. Previous research on culturally imbalanced books also shows that the role of learning materials is essential in shaping learners' ICC; hence an equal cultural portrayal is needed. This study may be a reference for further analysis of cultural content in English learning textbooks since this study is still limited to the reading sections of the books and not the whole sections. It is suggested that studies like this can also be done using different perspectives and theories.

\section{REFERENCES}

Cenoz, J., \& Jessner, U. (2000). English in Europe: the acquisition of a third language. Multilingual Matters.

Cortazzi, M., \& Jin, L. (1999). Cultural mirrors: Materials and methods in the EFL classroom. In Culture in Second Language Teaching and Learning (pp. 196-219). Cambridge University Press.

Gómez Rodríguez, L. F. (2015). The cultural content in EFL textbooks and what teachers need to do about it. PROFILE Issues in Teachers' Professional Development, 17(2), 167-187. https://doi.org/10.15446/profile.v17n2.44272

Hamiloğlu, K. and B. Mendi. (2010). A content analysis related to the crosscultural/intercultural elements used in EFL coursebooks. Sino-US English Teaching 7, no. 1: 16-24.

Kementerian Pendidikan dan Kebudayaan Republik Indonesia. (n.d.). www.kemdikbud.go.id. Retrieved July 7, 2020, from https://www.kemdikbud.go.id/main/tentangkemdikbud/visi-dan-misi

Lestari, S. (2015). Pengelolaan kurikulum muatan lokal (KML) bahasa Inggris SD negeri sekecamatan Gondokusuman Yogyakarta. Jurnal Penelitian Ilmu Pendidikan, 5(2). https://doi.org/10.21831/jpipfip.v5i2.4754

Miles, M. B., \& Huberman, A. M. (2012). An expanded coursebook qualitative data analysis. In Introduction to Educational research: A Critical Thinking Approach. Sage.

Munandar, M. I., \&Ulwiyah, I. (2012). Intercultural approaches to the cultural content of Indonesia's high school ELT textbooks. Cross-Cultural Communication, 8(5), 67-73. https://doi.org/10.3968/j.ccc.1923670020120805.975

Olaya, A., \& Gomez Rodriguez, L. F. (2013). Exploring EFL Pre-Service Teachers' Experience with Cultural Content and Intercultural Communicative Competence at Three Colombian Universities. Profile, 15, 49-67. 
Rahim, H. A., \&Daghigh, A. J. (2019). Locally developed versus global textbooks: an evaluation of cultural content in textbooks used in English language teaching in Malaysia. Asian Englishes, 1-15. https://doi.org/10.1080/13488678.2019.1669301

Rahmani, S. L. (2018). Cultural content analysis of an EFL textbook for higher education = analisiskontenbudayaterhadapbuku ajar bahasainggrisuntukperguruantinggi. Universitas Indonesia Library. http://lib.ui.ac.id/detail?id=20479063\&lokasi=lokal

Salyers, F., \&Mckee, C. (n.d.). The young adolescent learner. Annenberg Learner.

Sari, S. N. (2017). UnsurbudayadalambukupembelajaranbahasaInggris SMA di Indonesia = culture load in ELT textbooks for senior high school in Indonesia [Undergraduate Dissertation]. In Universitas Indonesia Library. http://lib.ui.ac.id/detail?id=20446988\&lokasi=lokal\#parentHorizontalTab5.

Suter, W. N. (2012). Introduction to educational research: A critical thinking approach (2nd ed.). Sage.

Tajeddin, Z., \& Teimournezhad, S. (2014). Exploring the hidden agenda in the representation of culture in international and localised ELT textbooks. The Language Learning Journal, 43(2), 180-193. doi: 10.1080/09571736.2013.869942

Wachidah, S., Gunawan, A., \& Diyantari. (2018). Bahasa Inggris: Think Globally Act Locally Kelas 9. Jakarta: KementerianPendidikandanKebudayaanRepublik Indonesia.

Wachidah, S., Gunawan, A., \& Diyantari. (2018). Bahasa Inggris: When English Rings a Bell Kelas 8. Jakarta: KementerianPendidikandanKebudayaanRepublik Indonesia.

Wachidah, S., Gunawan, A., \& Diyantari. (2018). Bahasa Inggris: When English Rings a Bell Kelas 7. Jakarta: KementerianPendidikandanKebudayaanRepublik Indonesia.

Weninger, C., \& Kiss, T. (2013). Culture in English as a foreign language (EFL) textbooks: A semiotic approach. TESOL Quarterly, 47(4), 694-716. https://doi.org/10.1002/tesq.87

Yuen, K. M. (2011). The representation of foreign cultures in English textbooks. ELT Journal, 65(4), 458-466. https://doi.org/10.1093/elt/ccq089 